\title{
Transnational Business as a Manifestation of the Integration of the Global Economy and a Driving Force of its Development
}

\author{
Svetlana S. Morkovina ${ }^{1}$; Alexandr S. Natsubidze2; Margarita S. Irizepova3; Nikolai G. Sinyavsky ${ }^{45}$; Vladimir V. Chashchin ${ }^{6}$
}

ABSTRACT The purpose of this article is to determine the significance of transnational business in the development of the global economic system, to present perspectives on its further functioning and distribution in the global economy, and to develop recommendations for state regulation of entrepreneurship in developing countries for the purposes of attracting transnational business and stimulating the internationalization of domestic business.

To achieve this purpose, the authors use statistical information combined with several methods: substantiation of mathematical expressions "by contradiction", structural analysis, classical methods of analyzing economic effectiveness, comparative analysis, problem and SWOT-analysis, systemic analysis, modeling of the current state of (and perspectives on) the development of economic systems, and formalization.

The authors reach the conclusion that transnational business is a manifestation and driving force of the development of the modern global economy and that maximization of the economic growth of the global economy in the long-term requires the creation of favorable conditions for further development of transnational business.

Transnational business plays an important role in the development of the global economic system. Perspectives on the further functioning and distribution of transnational business in the global economy are connected to the development of integration processes and the realization of a free trade policy. To overcome threats to the development of transnational business, the authors of this study offer recommendations for state regulation of business in developing countries for the purpose of attracting transnational business and stimulating the internationalization of domestic business, and a special model is developed.

KEY WORDS:

transnational business, integration of the global economy, driving force of development, developed countries, developing countries

JEL Classification: F630, 0190

'Voronezh State University of Forestry Engineering named after G.F. Morozov, Russia; ${ }^{2}$ Moscow International Academy, Russia; ${ }^{3}$ Volgograd State University, Russia; ${ }^{4}$ Volgograd State Agricultural University, Russia; ${ }^{5}$ Financial University under the Government of the Russian Federation, Russia; ${ }^{6}$ Ural State Institute of Stock Market, Russia

\section{Introduction}

Transnational business emerged from the influence of integration processes that shaped the global

\section{-}

Correspondence concerning this article should be addressed to: Alexandr S. Natsubidze, Moscow Institute of State and Corporate Management, Russia, 107023, Moscow, 21 Elektrozavodskaya St., Apt. 21, Tel.: +7-926-366-11-55, E-mail: sciencescience108@yahoo.com economy in the late $19^{\text {th }}$ and early $20^{\text {th }}$ centuries. This initiated a rapid acceleration of the development of the global economic system due to the movement of capital from the developed countries, which usually have an excess of financial resources, to the developing countries, which are known to have deficits and an urgent need for investment resources. 
When transnational businesses appeared in developing countries, they established production facilities, which provided new jobs for the local population and stimulated local purchasing ability, the development of entrepreneurship, and economic growth. This reflects the ability of transnational business to stimulate development in countries that need it but cannot independently close the gap that exists between them and developed countries.

During the modern stage of development of the global economy, transnational business became an inextricable part of the global economic system and one of its most important members, as it represents large business structures through which dialogue between the governments of various countries and business as a whole is conducted. Transnational corporations pursue their own interests, which, as the accumulated experience of transnational business shows, coincide largely with the global goals of economic development.

The unique capability of transnational business to revive the economies of developing countries by activating business activities, combined with its inclination for solving global economic problems (particularly problems of disproportionate economic growth in the global economy) makes it not only one of the most notable players in international economic relations but also one of the most promising mechanisms of improving the modern global economy.

Thus, the study of transnational business and its role in the development of the global economy is highly topical and is, accordingly, the focus of this article. The authors of this study propose the hypothesis that transnational business is a driving force behind the development of the modern global economy. Thus, to maximize the economic growth of the global economy in the long-term, it is necessary to create favorable conditions for the further development of transnational business.

The purpose of this research is to verify this hypothesis, determine the meaning of transnational business in the development of the global economic system, determine perspectives on its further functioning and distribution in the global economy, and develop recommendations for state regulation of business in developing countries for the purpose of attracting transnational business and stimulating the internationalization of domestic business.

\section{Literature review}

The consequences of the globalization of the world economy; the notions, senses, and factors at play in the integration of processes in the modern global economic system; the role of international organizations in regulating these processes; the phenomena of regionalization and polarization of the global economy within the process of integration; and the causes of the possible future disintegration of the global economy - all these issues are explored in the works of such authors as (Burhan, Sidek, Kurniawan, \& Mohamad, 2015; Capello \& Perucca, 2015; Gozgor, 2015; Lauder \& Brown, 2015). Globalization has led to the growth of economic systems and their close cooperation (Egbetunde \& Akinlo, 2015). International organizations coordinate this process and provide support for underdeveloped countries, with the goal of unifying the global economic system (Vasin \& Gamidullaeva, 2015). However, there are still significant differences in the levels of economic development of countries around the world, which may be a reason for the disintegration of the global economy in the future (Lee, Lee, \& Chang, 2015).

Issues related to the specifics of economic growth in the modern global economy, the drivers of economic development, ways of overcoming crisis phenomena in the global economy, analysis of possibilities and perspectives related to further global economic growth, and determination of the most important factors that stimulate and hinder the achievement of the strategic development goals of global economic systems - these topics are studied in the works of such scholars as (González-Pernía \&,PeñaLegazkue, 2015; Leonida, Maimone Ansaldo Patti, Marini, \& Navarra, 2015; Odhiambo, 2015; Pogosov, 2015; Popkova, Yurev, Stepicheva, \& Denisov, 2015; Sarracino \& Bartolini, 2015; Zeira \& Zoabi, 2015). In today's globalizing environment, crisis phenomena that may have begun in one economic system can spread throughout the whole world (Choi \& Shin, 2015). Countries can overcome global crises only by uniting their efforts (Lee \& Oh, 2015). Despite the universality of strategic interests, most countries continue to seek their own goals of economic development, which hinders the development of the global economic system as a whole (Castiglione, Infante, \& Smirnova, 2015). 
Manifestations of the internationalization of business under the conditions of the integration and globalization of the world economy, the conditions necessary for the movement of production factors within the global economic system under the influence of the market mechanism, and internal stimuli that can improve the economic effectiveness of the organization of production and maximization of profit are examined in multiple studies by contemporary authors, including works by (Debrulle \& Maes, 2015; Guillotin \& Mangematin, 2015; Monteiro \& Meneses, 2015; Purkayastha, Manolova, \& Edelman, 2015). Under the conditions of integration and globalization of the world economy, the internationalization of business activities is ongoing. In this setting, both local and national business enters the international level (Ginting, 2014). In today's globalizing world, under the influence of market mechanisms and internal stimuli, production factors move within the global economic system (Eisend \& Schmidt, 2014) to increase the economic effectiveness of production and maximize profit (Ahmad, 2014).

Many authors have studied various aspects of the manifestation of transnational business and its further distribution in the global economic system; its role in business development, overcoming the gaps between developing countries, and reducing disproportionate economic growth in the modern global economy; the specifics of the work of transnational corporations; and issues of state regulation of transnational business activities. Such authors include (Bagwell, 2015; Delteil, 2014; Lan, 2015; Thauer, 2015). Transnational business plays an important role in the development of business, as it provides access to new sales markets and cheaper resources, which increases the effectiveness of business (Eberlein, Abbott, Black, Meidinger, \& Wood, 2014). Transnational business also contributes to overcoming the gaps between developing countries and to reducing disproportionate economic growth in the modern global economy by means of developing trade and business - and by moving resources into developed countries and capital into developing ones (Porter, 2014). State regulation of the activities of transnational corporations is performed at present and is aimed at the protection of internal markets (Lee, Ryu, \& Kang, 2014).
The large volume of materials on this topic creates a strong theoretical base, but it does not mean there is no need for new research. Issues relating to the ability of transnational business to be a driving force behind the development of the global economy are of high scientific and practical interest, as are the possibilities of realizing such an economic policy in developing countries. This would produce the maximum advantages from the functioning of transnational business, making this research both necessary and important.

\section{Method}

To achieve its stated goal, this work uses general scientific methods of research: induction, deduction, and synthesis. Determining the meaning of transnational business in the development of the global economic system requires research in two key directions. First, it is advisable to substantiate the necessity of transnational corporations in the development of the global economy.

For this, the authors use both analysis of statistical information and evidence of mathematical expressions "by contradiction", within which - on the basis of the basic laws of logic and the principle of double negation - the possibility of eliminating transnational business from the structure of elements of the global GDP is determined.

Second, there is a need to determine the level of economic effectiveness of the functioning of transnational business. For this, the authors use the method of structural analysis, classical methods of analysis of economic effectiveness, and the method of comparative analysis. These are used to compare the levels of economic effectiveness of the activities of transnational business and national business, through comparison of the resources used, efficiency of production, and contribution to global GDP.

To determine perspectives on the further functioning of transnational business and its distribution in the global economy, the authors of this study use the method of problem and SWOT-analysis, with the help of which the advantages and disadvantages of transnational business - compared to national business - as well as possibilities of and threats to the development of transnational corporations in the short-term are determined.

To determine the causal relations involved in realizing the recommendations developed here regarding 
state regulation of business in developing countries for the purpose of attracting transnational business and stimulating the internationalization of domestic business, this work uses systemic analysis, modeling of the current situation, perspectives on the development of economic systems, and the method of formalization.

\section{Results}

According to official statistics provided by the international organization UNCTAD in 2015, transnational business creates approximately $10 \%$ of global employment (Fig. 1), more than $40 \%$ of global production (Fig. 2), almost $60 \%$ of direct foreign investments (Fig. 3,4 ), and $80 \%$ of global innovation production (Fig. 5).

Analysis of statistical information, presented graphically in Fig. 1-5, shows that transnational business has been playing an important role in the functioning and development of the global economy in recent decades. To determine the need for transnational corporations in the development of the global economy, let us build a mathematical model of the formation of the global GDP.

According to the official UNCTAD statistics for $2014,70 \%$ of global GDP is based on the manufacture of standard products, and $30 \%$ is based on the manufacture of innovative products, $80 \%$ of which are manufactured by transnational business and $20 \%$ by national business. On the basis of the above, it is possible to create a structural and logical model of the formation of global GDP, as follows:

GDPworld $=0.7 \mathrm{UP}+0.3(0.8 \mathrm{~TB}+0.2 \mathrm{NB})$

where GDPworld - global GDP;

UP - products that are not innovative;

$\mathrm{TB}$ - transnational business;

NB - national business.

On the basis of existing statistical information, let us insert values into this model and produce the following equation: $77,302=54,111 \mathrm{UP}+18,552 \mathrm{~TB}+4,638 \mathrm{NB}$. Let us suppose that transnational business contributes greatly to the development of the global economy and formation of the global GDP. Then, $\mathrm{TB} \approx 0$.

In this case, the equation has the following form: $77,302=54,111 \mathrm{UP}+4,638 \mathrm{NB}$. While the values of various sides of this equation are not equal and differ from each other $(77,302>58,749)$, this contradicts the initial suppo- sition of the insignificance of transnational business' contribution to the formation of the global GDP and proves that it is indeed an important component of the development of the global economy, according to the 2014 data.

To determine the level of economic effectiveness of transnational business, let us determine the structure of innovative products. To develop innovative technologies and purchase equipment necessary for the manufacture of innovative products, investments are necessary. Innovative products are manufactured by employees who represent the human resources of enterprises. Consequently, in its general form, the model of manufacture of innovative products could be presented in the following way:

$\mathrm{HR}^{\star} \mathrm{IR}=\mathrm{IP}$

where HR - human resources;

IR - investment resources;

IP - innovative products.

According to the UNCTAD statistics for 2014, 10\% of global human resources are concentrated in transnational business, which, in turn, accumulates $60 \%$ of global investment resources and manufactures $80 \%$ of global innovative products. This allows a mathematical presentation of the contribution of transnational business to the manufacture of innovative products, as follows: $0.1 \mathrm{HR}^{\star} 0.6 \mathrm{IR}=0.8 \mathrm{IP}$.

Then, the contribution of national business to the manufacture of innovative products will have the following form: $0.9 \mathrm{HR}^{\star} 0.4 \mathrm{IR}=0.2 \mathrm{IP}$. To evaluate effectiveness, let us use such economic indicators as labor efficiency (determined as the ratio of manufactured innovative products to the human resources used) and capital intensity of production (calculated as the ratio of investment resources used for the manufacture of innovative products).

The labor efficiency of transnational business during the manufacture of innovative products is calculated as follows: $0.8 \mathrm{IP} / 0.1 \mathrm{HR}=0.8 \$$ million/person. The labor efficiency of national business during the manufacture of innovative products is calculated as follows: $0.2 \mathrm{IP} / 0.8 \mathrm{HR}=\$ 0.25 \mathrm{million} /$ person. It is obvious that $\$ 0.8 \mathrm{million} /$ person> $\$ 0.25 \mathrm{million} /$ person, which proves that labor efficiency is higher in the sphere of transnational business. 


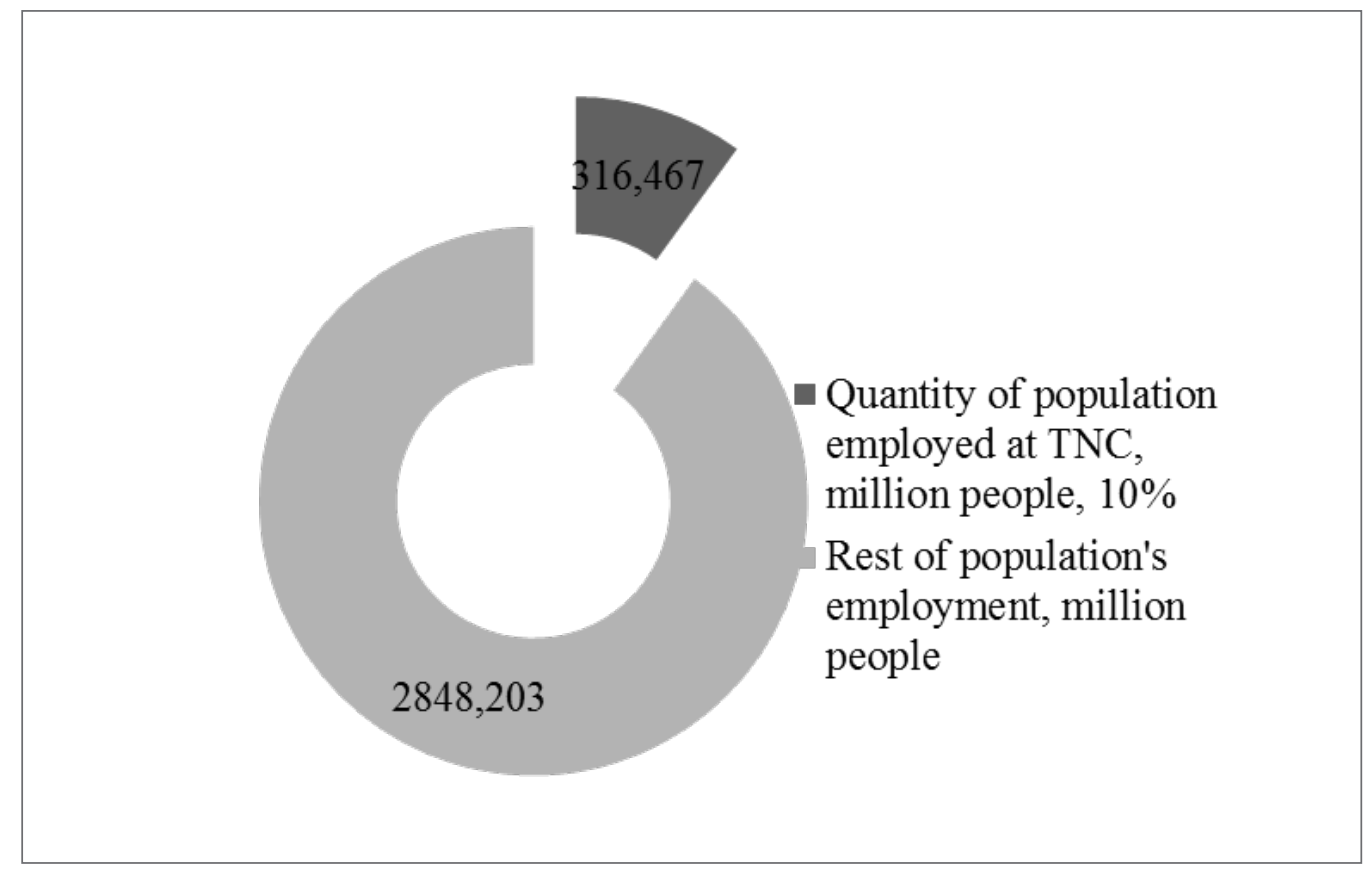

Figure 1. Structure of global employment in 2014

Source: United Nations Conference on Trade and Development, 2015.

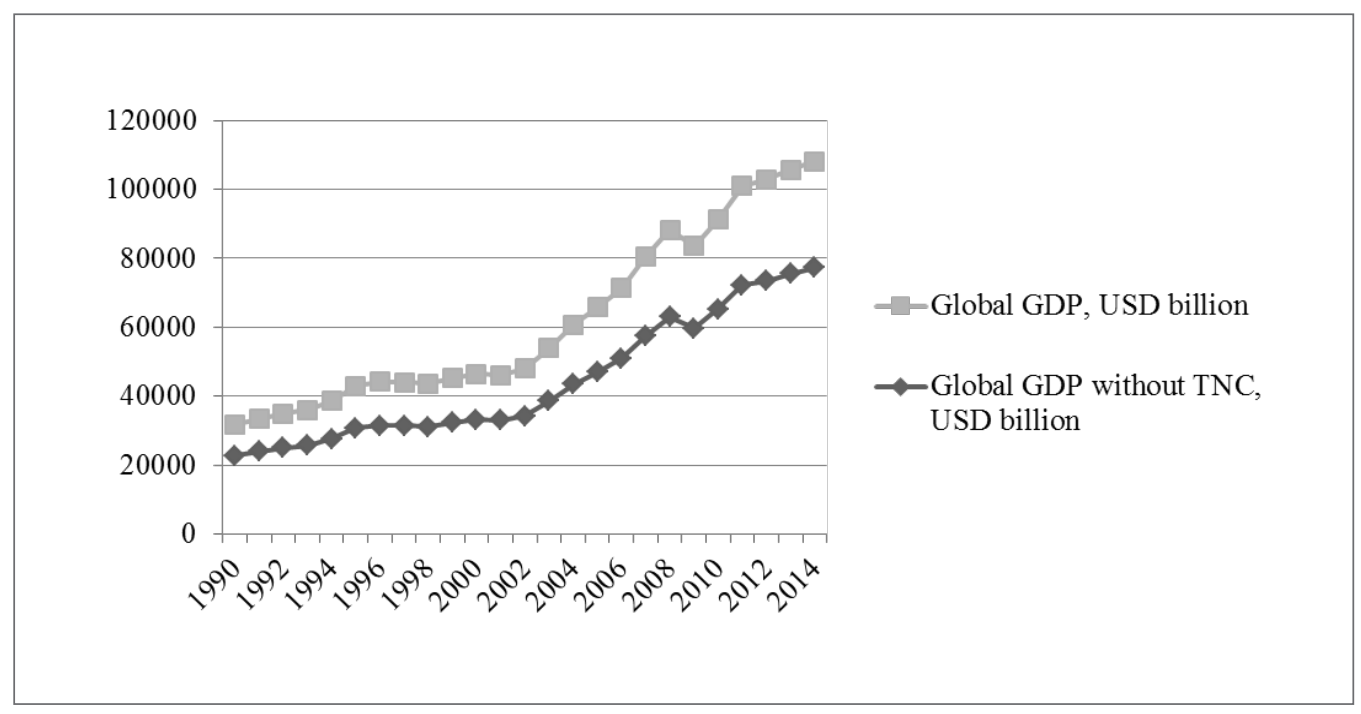

Figure 2. Statistics of global GDP with and without TNC in 1990-2014 Source: KNOEMA, 2016. 


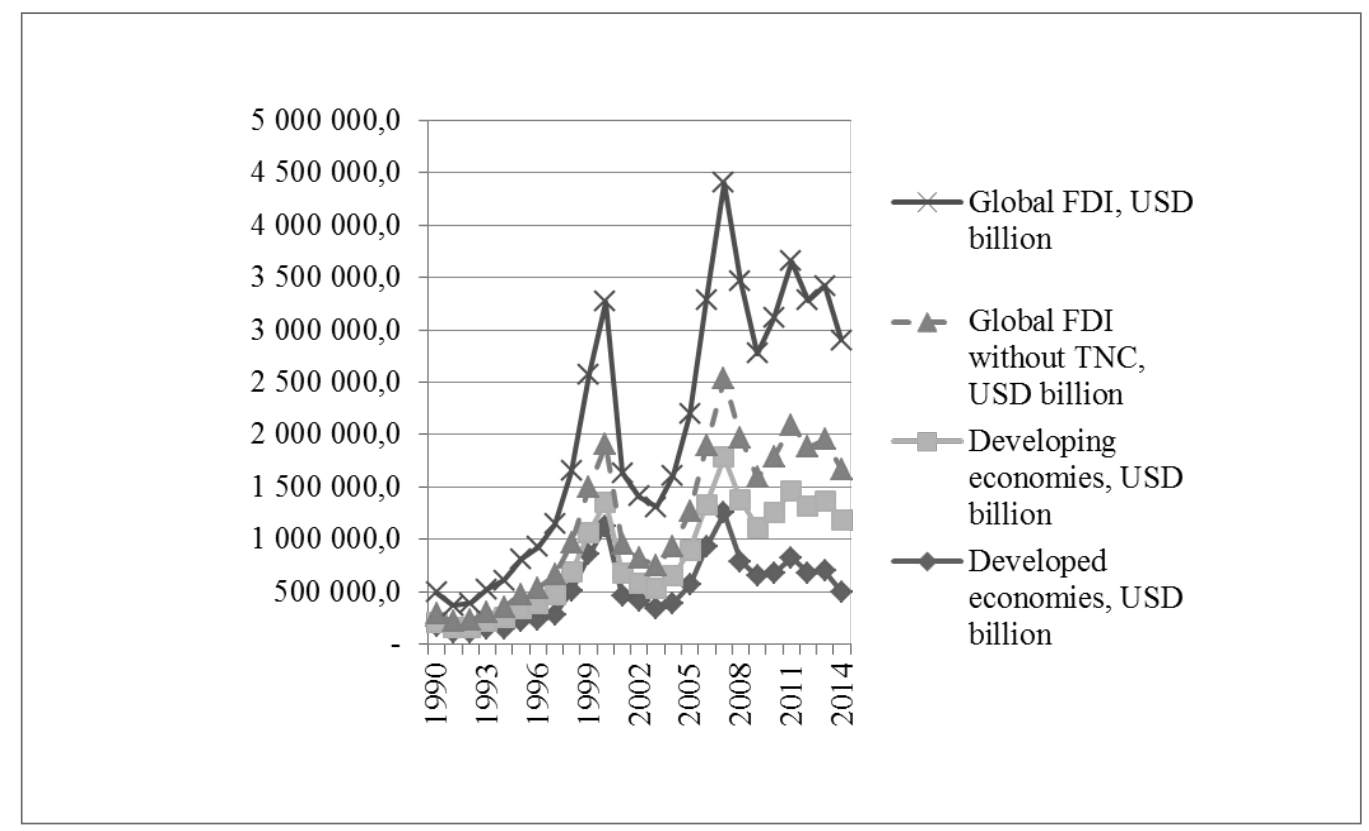

Figure 3. Statistics on global direct foreign investments in 1990-2014 Source: United Nations Conference on Trade and Development, 2016.

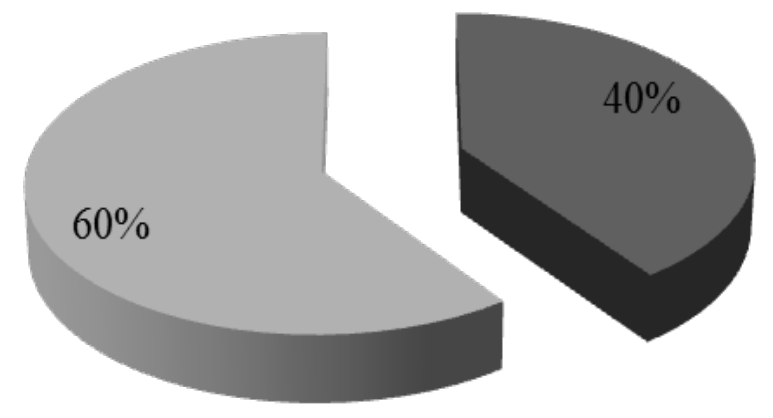

$\square$ FDI of TNC $\quad$ Rest of global FDI

Figure 4. Structure of global direct investments in 2014

Source: United Nations Conference on Trade and Development, 2016 


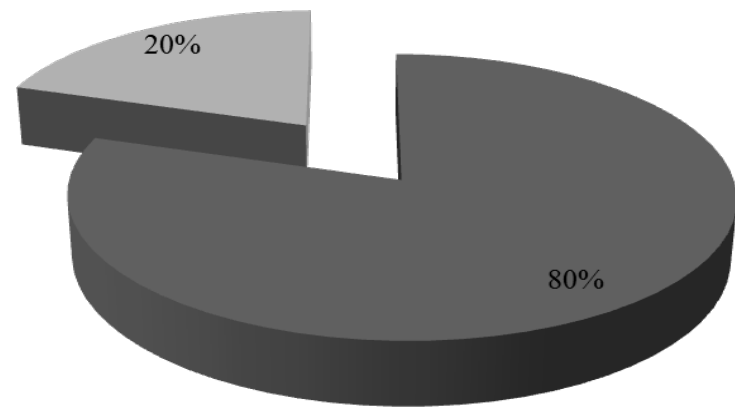

- Innovational products, created by TNC

Innovational products, created by national enterprises

Figure 5. Structure of global innovative production in 2014

Source: United Nations Conference on Trade and Development, 2015

Table 2. SWOT-analysis of development of transnational business

\begin{tabular}{ll}
\hline Advantages of transnational business (S) & Disadvantages of transnational business (W) \\
\hline high effectiveness of production & striving for minimization of taxes \\
high innovative activity & inclination toward monopolization of markets \\
high mobility of production & ecological irresponsibility \\
stimulation of global production & increased risks to business \\
Perspectives on development of transnational business $(\mathrm{O})$ & Threats to development of transnational business (T) \\
development of integration processes in the global economy & tendency for disintegration of the global economy \\
weakening of customs barriers within policy of free trade & strengthening of customs barriers within policy of protectionism \\
\hline
\end{tabular}

The capital intensity of manufacturing innovative products in the sphere of transnational business is calculated as follows: $0.6 \mathrm{IR} / 0.8 \mathrm{IP}=\$ 0.75$ million. In other words, to manufacture innovative products that cost $\$ 1$ million, transnational corporations need $\$ 0.75$ million in investment resources. The capital intensity of manufacturing innovative products in the sphere of national business is calculated as follows: $0.4 \mathrm{IR} / 0.2 \mathrm{IP}=\$ 2 \mathrm{mil}-$ lion. In other words, to manufacture innovative products that cost $\$ 1$ million, national corporations need $\$ 2$ million in investment resources.

In comparing these values, it is clear that $\$ 2$ million $>\$ 0.75$ million, which reflects the lower capital in- tensity and higher effectiveness of transnational business' manufacture of innovative products. It should be noted that despite its high effectiveness and important role in the development of the global economy, transnational business often faces obstacles.

Transnational business possesses many advantages compared to national business: highly effective production, significant innovative activity due to the presence of necessary resources, high mobility of production due to the lack of a fixed connection to a specific territory, and stimulation of global production.

At the same time, there are drawbacks to transnational business. These are related to its goal of mini- 


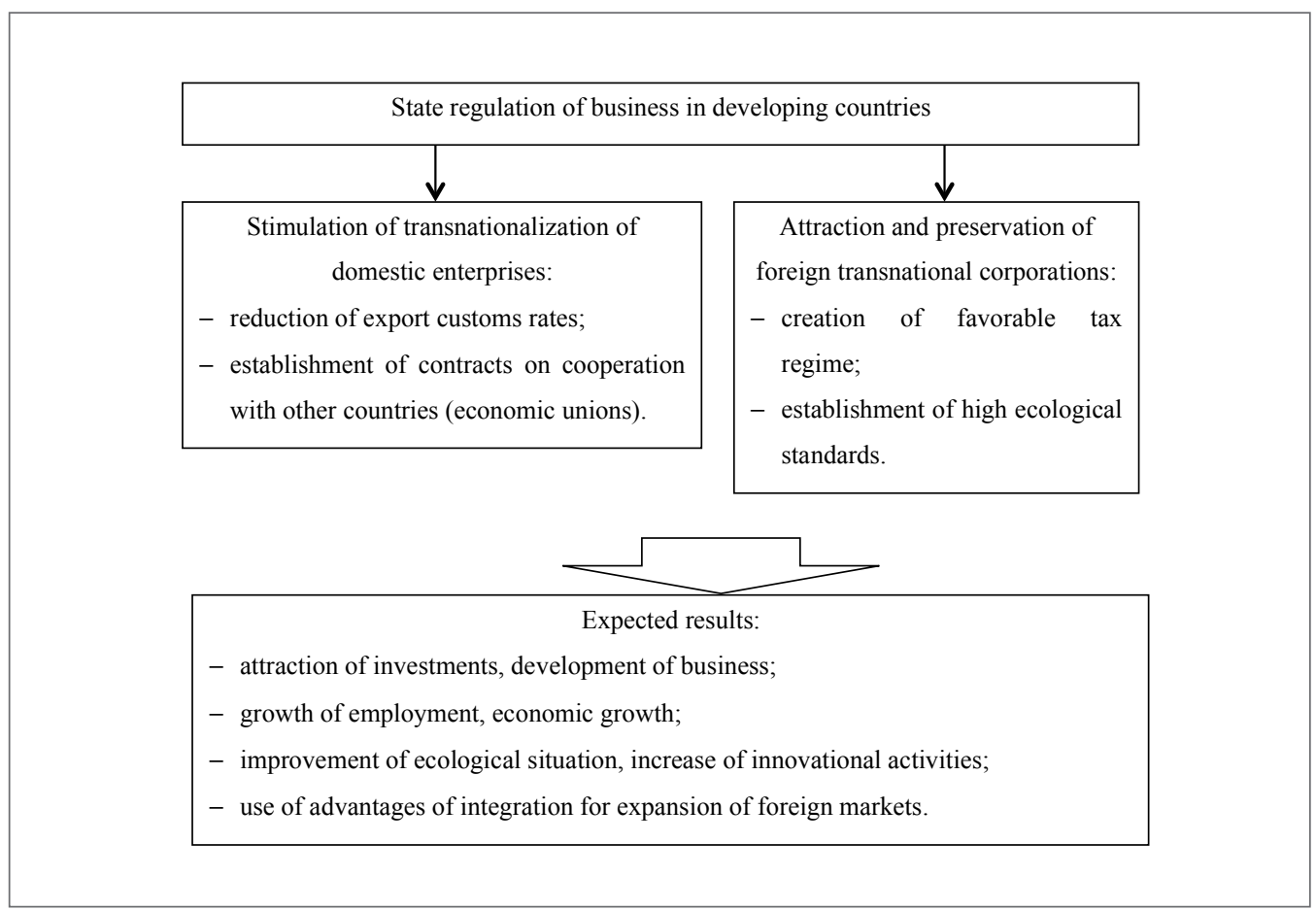

Figure 6. Model of development of transnational business as a result of realization of the proposed measures for state regulation of business in developing countries

mizing the taxes it pays, its inclination to monopolize markets, its transfer of ecologically dangerous production into developing countries, and the increase in business risks due to the probability of transnational corporations' leaving countries with unfavorable situations, which can lead to crisis phenomena in these countries' economies.

The results of SWOT-analysis of the development of transnational business are shown in Table 1. As seen in Table 1, perspectives on the further functioning and distribution of transnational business in the global economy are related to the development of integration processes and realization of the policy of free trade. In the case of the opposite tendency - disintegration of the global economy - it is possible to wait for a reduction in transnational business. A threat to its development is posed by the strengthening of customs barriers within the policy of protectionism.
As the recent global financial crisis showed, under conditions of instability, the governments of various countries are interested in the preservation of domestic production and may use tools to protect national business, which may disadvantage the interests of transnational corporations. Announcements from a range of territories regarding their wish to leave various associations - of which they are now members show the high probability of the disintegration of the global economy in the near future.

To reduce the above threats, some possible recommendations for state regulation of business in developing countries - for the purpose of attracting transnational business and stimulating the internationalization of domestic entrepreneurship - can be offered: reduction in export custom rates, establishment of contracts regarding cooperation with other countries (economic unions), creation of favorable tax 
regimes, and establishment of high ecological standards. The causal relations involved in the realization of these recommendations and the development of transnational business are shown in Fig. 6.

\section{Conclusion}

As a result of this research, the proposed hypothesis was proven, and it was substantiated that transnational business is a manifestation and driving force of the development of the modern global economy. Maximizing the economic growth of the global economy in the long-term requires the creation of favorable conditions for further development of transnational business.

Transnational business plays an important role in the development of the global economic system: it provides approximately $10 \%$ of global employment, more than $40 \%$ of global production, almost $60 \%$ of direct foreign investments, and $80 \%$ of global innovative production.

The use of mathematical tools showed that the capital intensity with which transnational business manufactures innovative products is much lower than that of national business, and labor efficiency in the sphere of transnational business is also much lower, which proves its high effectiveness.

Perspectives on the further functioning and distribution of transnational business in the global economy are related to the development of integration processes and realization of the policy of free trade. To overcome threats to the development of transnational business, the authors of this study offer recommendations for state regulation of business in developing countries for the purpose of attracting transnational business and stimulating the internationalization of domestic entrepreneurship.

These recommendations are reflected in the proprietary model of the development of transnational business as a result of the realization of the proposed measures of state regulation of business in developing countries, within which two directions of state economic policy are offered: stimulation of transnationalization of domestic enterprises and attraction and preservation of foreign transnational corporations.

Realization of this model will lead to increased investments, development of business, higher employment, economic growth, improvement of the ecological situation, increased innovative activity, and the use of the advantages of integration for the expansion of foreign markets. It should be noted that this model is oriented toward developing countries - however, developed countries are equally interested in the development of transnational business and attracting transnational corporations.

This is why determining the possible directions of state regulation of business in developed countries (for the purpose of stimulating the transnationalization of domestic enterprises) and attracting and preserving foreign transnational corporations have major scientific and practical significance and are interesting avenues for further research in this sphere.

The theory of transnationalization of entrepreneurial activities may receive further development due to the expansion of integration processes in the global economy. This requires the development of theoretical and methodological provisions regarding the creation of a corresponding institutional environment that stimulates the development of transnational business.

\section{References}

Ahmad, S. Z. (2014). Small and medium enterprises' internationalisation and business strategy: Some evidence from firms located in an emerging market. Journal of Asia Business Studies, 8(2), 168-186.

Bagwell, S. (2015). Transnational entrepreneurship amongst Vietnamese businesses in London. Journal of Ethnic and Migration Studies, 41(2), 329-349.

Burhan, N. A. S., Sidek, A.H., Kurniawan, Y., Mohamad, M. R. (2015). Has globalization triggered collective impact of national intelligence on economic growth? Intelligence, 48, 152-161.

Capello, R., Perucca, G. (2015). Openness to globalization and regional growth patterns in CEE countries: From the EU accession to the economic crisis. Journal of Common Market Studies, 53(2), 218-236.

Castiglione, C., Infante, D., \& Smirnova, J. (2015). Environment and economic growth: is the rule of law the go-between? The case of high-income countries. Energy, Sustainability and Society, 5(26). doi:10.1186/s13705-015-0054-8.

Choi, K. H., Shin, S. (2015). Population aging, economic growth, and the social transmission of human capital: An analysis with an overlapping generations model. Economic Modelling, 50, 138-147. 
Debrulle, J., Maes, J. (2015). Start-ups' internationalization: The impact of business owners' management experience, start-up experience and professional network on export intensity. European Management Review, 12(3), 171-187.

Delteil, V. (2014). Domestic labor regulation and foreign business influence: The case of the Guangdong transnational capitalism. In X. Richet, V. Delteil, \& P. Dieuaide (Eds.), Strategies of multinational corporations and social regulations. European and Asian Perspectives (pp. 219-240). Berlin: Springer Verlag.

Eberlein, B., Abbott, K. W., Black, J., Meidinger, E., Wood, S. (2014). Transnational business governance interactions: Conceptualization and framework for analysis. Regulation and Governance, $8(1), 1-21$.

Egbetunde, T., Akinlo, A. E. (2015). Financial globalization and economic growth in Sub-Saharan Africa: Evidence from panel cointegration tests. African Development Review, 27(3), 187-198.

Eisend, M., Schmidt, S. (2014). The influence of knowledge-based resources and business scholars' internationalization strategies on research performance. Research Policy, 43(1), 48-59.

Ginting, G. (2014). Proposed conceptual model internationalization of small medium industries (SMIs) in Indonesia: The relationship between entreprenurial orientation, network capital, degree of internationalization and business performance. Asian Social Science, 10(19), 220-229.

González-Pernía, J. L., Peña-Legazkue, I. (2015). Export-oriented entrepreneurship and regional economic growth. Small Business Economics, 45(3), 505-522.

Gozgor, G. (2015). Causal relation between economic growth and domestic credit in the economic globalization: Evidence from the Hatemi-J's test. The Journal of International Trade and Economic Development, 24(3), 395-408.

Guillotin, B., \& Mangematin, V. (2015). Internationalization Strategies of Business Schools: How Flat Is the World? Thunderbird International Business Review, 57(5), 343-357.

Knoema. (2016). World GDP 1980-2014. Retrieved from http://knoema.ru/tbocwag/gdp-by-country1980-2014? country=Мир
Lan, S. (2015). Transnational business and family strategies among Chinese/Nigerian couples in Guangzhou and Lagos. Asian Anthropology, 14(2), 133-149.

Lauder, H., \& Brown, P. (2015). Economic globalisation, skill formation and development. In S. McGrath, Q. Gu (Eds.), Routledge Handbook of International Education and Development (pp. 303-312). London, UK: Routlege.

Lee, J. Y., Ryu, S., \& Kang, J. (2014). Transnational HR network learning in Korean business groups and the performance of their subsidiaries. The International Journal of Human Resource Management, 25(4), 588-608.

Lee, C. C., Lee, C. C., Chang, C. P. (2015). Globalization, economic growth and institutional development in China. Global Economic Review, 44(1), 31-63.

Lee, S., Oh, D. W. (2015). Economic growth and the environment in China: Empirical evidence using prefecture level data. China Economic Review, 36, 73-85.

Leonida, L., Maimone Ansaldo Patti, D., Marini, A., Navarra, P. (2015). Political competition and economic growth: A test of two tales. Economics Letters, 135, 96-99.

Monteiro, R., Meneses, R. (2015). The relevance of business diplomacy in internationalisation processes: An empirical study. International Journal of Business and Globalisation, 15(1), 20-44.

Odhiambo, N. M. (2015). Government expenditure and economic growth in South Africa: An empirical investigation. Atlantic Economic Journal, 43(3), 393-406.

Pogosov, I. A. (2015). Factors of long-term economic growth: Scientific and technical progress and capital intensity of production. Studies on Russian Economic Development, 26(5), 423-433.

Popkova, E. G., Yurev, V., Stepicheva, O., Denisov, N. (2015). Transformation and concentration of intellectual capital as a factor of economic growth in the modern economy. Regional and Sectoral Economic Studies, 15(1), 53-60.

Porter, T. (2014). Technical systems and the architecture of transnational business governance interactions. Regulation and Governance, 8(1), 110-125.

Purkayastha, S., Manolova, T. S., \& Edelman, L. F. (2015). Business group effects on the innovationinternationalization relationship: Evidence from the Indian Pharmaceutical Sector. In L. Tihanyi, E. 
R. Banalieva , T. M. Devinney, T. Pedersen (Eds.), Emerging economies and multinational enterprises (Advances in International Management, Vol. 28, pp. 379-402). Bingley, UK: Emerald Group Publishing Limited.

Sarracino, F., Bartolini, S. (2015). The dark side of Chinese growth: Declining social capital and wellbeing in times of economic boom. World Development, 74, 333-351.

Thauer, C. R. (2015). In need of meta-governance: Business networks of transnational governance. Israel Law Review, 48(2), 189-218.

United Nations Conference on Trade and Development. (2015). Transnational Corporations Statistics (2015). Retrieved from http://unctad.org/en/ Pages/DIAE/Transnational-Corporations-Statistics.aspx

United Nations Conference on Trade and Development. (2016). FDI inflows, by region and economy, 1990-2014 Retrieved from http://unctad. org/en/Pages/DIAE/World\%20Investment\%20 Report/Annex-Tables.aspx

Vasin, S. M., Gamidullaeva, L. A. (2015). Methodical approach and tools to improve the efficiency of managing of the innovation potential in the context of economic globalization. Review of European Studies, 7(3), 124-139.

Zeira, J., Zoabi, H. (2015). Economic growth and sector dynamics. European Economic Review, 79, 1-15. 
